\title{
Research on the European and American Music Education Mode and Corresponding Influence on the Chinese Native Music Education
}

\author{
Fei $\mathrm{Li}^{1}$, \\ ${ }^{1}$ School of Music , \\ Jiangxi Science \& Technology Normal \\ University, \\ Nanchang,China
}

\author{
$\mathrm{Li} \mathrm{Xu^{2 }}$ \\ 2 Jiangxi Science \& Technology Normal \\ University, \\ Nanchang,China
}

\begin{abstract}
In this paper, we research on the European and American music education mode and corresponding influence on the Chinese native music education. At present our country education system reform has come to a critical period, especially the education reform in colleges and universities in the new stage of development. The serious influence is the quality of music teaching. Colleges and universities music education make and manage the school, the school for students to adopt a unified education model, unified teaching materials and teaching methods, make the music education of the college unification. Our proposed approach combines the advances of western education pattern with the native music education which will be effective and innovative.
\end{abstract}

Keywords: Music Education; European and American; Chinese Native; Influence and Impact.

\section{Introduction}

Our country is a long history of civilization, has long attached great importance to music education related work, in the long history of China, formed its own unique music culture and music appreciation system. Not only that, music is our country ancient Kings over an important policies in China, plays a very important role in business. Since the founding of the people, China's music education cause rapid development and emerged a large number of music talent. Traditional music teaching mode, the students become passive receptors, which to improve the students' comprehensive ability caused great obstacles. The serious influence is the quality of music teaching. Colleges and universities music education uses research-based teaching mode, changed the original teaching mode, can make students in the teaching process of constantly digging their own potential, training their own ability. Students to be active in the whole teaching process, enables the student in the teaching to feel the music. Thus greatly enhance the students' comprehensive ability, so as to improve the quality of university teaching music [1-2]. In colleges and universities music education to take the research-oriented teaching mode in must be carried out in accordance with the relevant principles, so as to give full play to the characteristics of research-based teaching. Teachers according to the college music education research teaching in-depth research, to understand the teaching of each process, so as to ensure its teaching can have very good effect. In the whole process of research-oriented teaching, the teacher is the main body of the whole process, only the teachers' understanding of the whole teaching process with clarity, to ensure that music education research teaching goes on smoothly so as to make the students' comprehensive ability was improved.

At present our country education system reform has come to a critical period, especially the education reform in colleges and universities in the new stage of development. In order to ensure that can adapt to the needs of the new curriculum reform education pattern in colleges and universities, and to better improve the students' skill training student's quality, universities have to reform the existing education mode [3]. Colleges and universities music education make and 
manage the school, the school for students to adopt a unified education model, unified teaching materials and teaching methods, make the music education of the college unification. The advantages of this kind of education mode is convenient manage school of music college, to improve the management efficiency which will reduce the management difficulty. Based on the original college music education mode could not adapt to the new development situation, colleges and universities music education mode must implement reform and breakthrough. Multicultural education is one of the hot issues in today's world education, it is a strong theoretical thoughts, is also a profound change practice. Multicultural education is an ambiguous concept, more different cultural group or in different countries, the understanding of the concept is different. Analysis summary foreign multicultural music education theories and methods, review our university music education, the development situation of how colleges and universities in our country, especially the local colleges and universities music education in a multicultural music education which is related to our country's colleges and universities music education for the future development of great things [4].

To optimize the Chinese native music education quality and pattern, in this paper, we research on the European and American music education mode and corresponding influence on the Chinese native music education. Today, in the implementation of higher education internationalization, the world's superpower is bearing the brunt of the United States, the United States to safeguard their own interests in the world, with particular emphasis on the international, cross-cultural and global ideas into institutions of higher learning from various aspects, such as teaching, scientific research and social service in university should cultivate a face with a "global view" the internationalization of the spirit of quality. Moreover, we combine the state-of-the-art multimedia based education pattern to modify the current teaching method which will be shown in the following sections.

\section{The Proposed Methodology}

The Current Chinese Native Music Education. In recent years, China's colleges and universities music education has made gratifying achievements and rapid development. However, we must clearly see that the current our country university music education there is still lack of correct understanding, the students' knowledge of music is not a comprehensive system, music teachers are weak such outstanding difficulties and problems. Existing in colleges and universities music education pattern is under the influence of the original system of education, lack of innovation and vitality, on the teaching achievement, to little effect. And because the rigid education mode, the potential of students didn't get development and the teaching quality is low for a long time. At present our country's colleges and universities music education model reform, although has successfully explored the credit system is the effective method, but in the concrete teaching practice, education patterns still exist many problems, we must further deepen further strengthened.

In addition to the obvious effect for students to promote credit system, is of epoch-making significance for music teaching model reform in colleges and universities. It is conceivable that in the original music teaching mode, teachers and students ideas were confined to the narrow scope, unable to realize the significance of music teaching mode reform, unable to colleges and universities music education mode for breakthrough, more can't realize the education of students of differentiation. In the figure one, we illustrate the challenges for Chinese native music education.

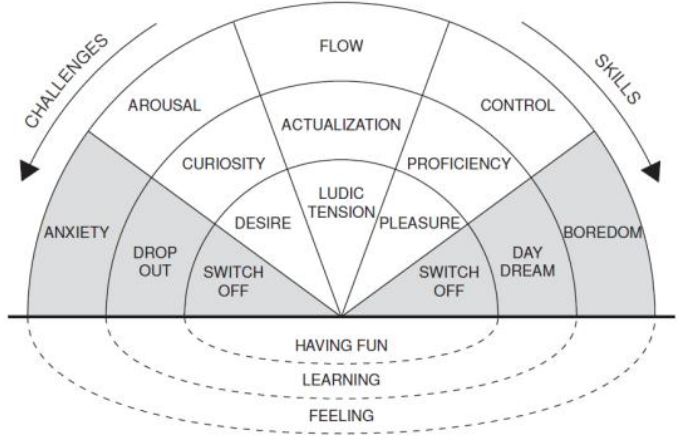


Figure 1. The Challenges for Chinese Native Music Education

\section{The European and American Music}

Education. On the teaching concept, the west is very pay attention to the development of the basic knowledge and basic ability of students. As a junior student the teaching is based on the singing training and training as the main goal, especially the European classical pie period of art songs as this one phase of the main teaching content. In some schools even strictly limited teaching repertoire for early classical works. Western music colleges and normal universities mainly consist of three parts: professional required course, theory and science courses, education courses teaching research. Also is a professional required course. These courses are more open and generalized. Teaching content is not deep. But maximize the training the students accept and creation as well as the ability to create music again. Theory and science classes and pay attention to cultivate the students' basic music theory and solid theoretical accomplishment. And fully understand the music of personality and social function. American culture, it is from the many ethnic and conception of culture, tradition and background of the rich. This diversity provides U.S. students with the advantage of learning, "the cultural diversity of the United States is the enormous resources, art education should fully exploit," to help students understand themselves and others. In a diverse international music education idea, the ethnic minority music because of its multiple features, more show incomparable unique value. Only national is the world, in this world, under the trend of ethnic minority music should strengthen their own music with their different regional culture resources, give full play to the multiple qualities, into the world of multicultural education system. Although the British music education rooted in the European classical tradition, but it is paying attention to the world of music at the same time and also try to dig the own national music culture wealth.

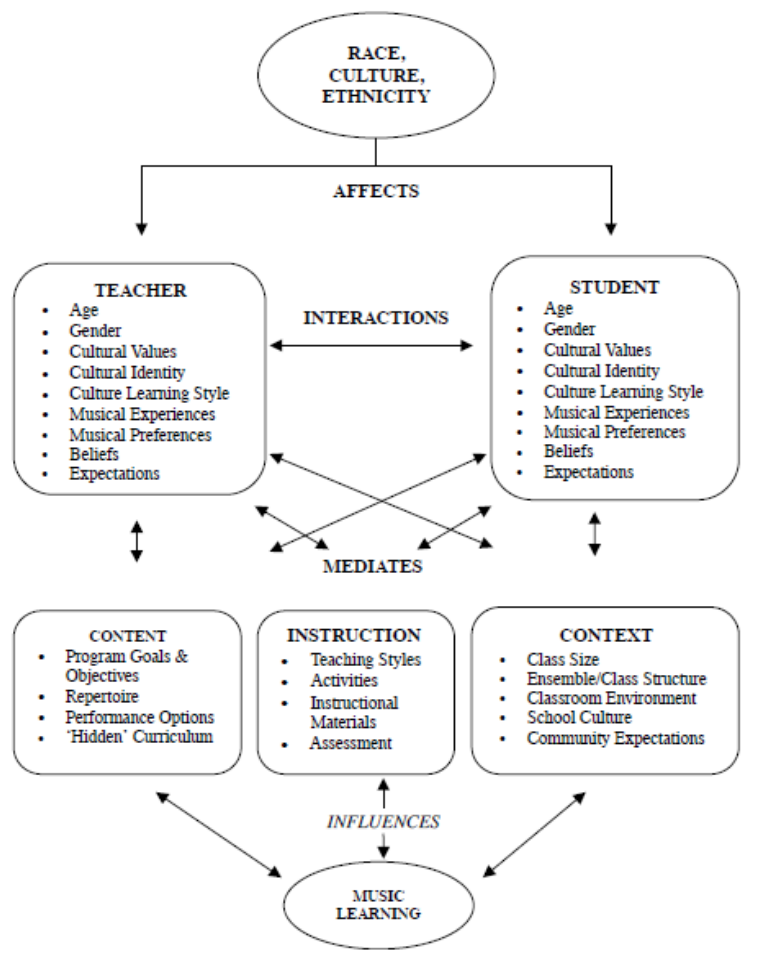

Figure 2. The Methodology Adopted by the European and American Music Education

In the figure two, we illustrate the popular methodology adopted by the european and american music education. Many music education workers has made many attempts in this aspect, such as add visual elements, in music appreciation of the auditory and visual organ motion, enhance the artistic appeal of music works, music art development up to now, already more and more harmony and other kinds of art, such as in the contemporary. Music art with the aid of the recording technology and communication technology revolution, make its influence to further expand the scope of, especially the application of multimedia technology in music art education, to enrich content of music art performance, enhance the effect of art education. Multicultural music education, is a very important education concept. For ordinary colleges and universities, is related to music education in how to spread and shape cultural values in the new century, and how to shape the character, ability, thinking in the future of the social and behavioral problems. 
In the west of the conservatory, all of the assessment, examination and concert hall. The teaching building of the hall there will be one side wall poster. It filled from this month to the next month's concert, posters and other music information examination. Colleges and universities is one of the important channels of multiple music spread national culture, college students should not only study in western Europe or the Chinese culture as the main body of the music, and therefore more should be based on the understanding of all ethnic groups and even the world music culture, understanding and respect culture in the culture, it sets up the equality of diverse cultural values.

\section{The Combination of Native and the Abroad}

Education Model. In colleges and universities music education research in the process of teaching, we should adopt the implementation of the scientific and reasonable method to ensure its normal, so that the colleges and the universities music education research teaching smoothly, thus making the students' professional ability and overall quality improved. We combine the general concepts of multicultural education pattern to show the following suggestions. (1) Ensure college music education research of exploratory teaching. In college music education in the research-oriented teaching, exploring is the distinctive features of teaching. In the process of teaching, the teacher wants to make this feature fully play, make the students in the teaching constantly, so as to improve their ability to find and solve problems. (2) Innovation concept of music teaching in colleges and universities, the establishment of creative music teachers. Old problem for colleges and universities music education concept, to strive for innovative ideas on music teaching in colleges, to broadening the channels for talent introduction, recruitment has innovation consciousness and innovation ability of music teachers, establishing creative music teachers. (3) Ensure college music education research-oriented teaching practice. Practicality and universities music education is an important feature of research-based teaching. So in the teaching we should pay attention to let the student to experience from practice, such ability to understand music. (4) Rich in colleges and universities music education resources to break the general music education development bottlenecks. Openness and research-oriented teaching problems need attention. Only in the open teaching mode, the minds of students to be more open, so as to make the students' various aspects ability get promoted. In a word, music is a many characteristics of a particular subject along with the advance of society and education career development. Taking colleges and universities music education of research-oriented teaching mode is the inevitable requirement. In specific teaching, we should according to the actual situation, adopt scientific and reasonable method to carry on the investigative teaching, so as to make the teaching quality improvement.

\section{Conclusion}

In this paper, we research on the European and American music education mode and corresponding influence on the Chinese native music education. Music education in essence belongs to the art education, music education embodies a kind of unique artistic beauty, but also in the sound of the national education mechanism, also has the function of aesthetic education. So, in this sense, music education is the most basic property is aesthetic and it is a kind of aesthetic education through music. Therefore, modify and correct understanding and analysis of university music education existing problems and put forward the corresponding countermeasure to improve the music education quality is of great significance. In the near future, we plan to conduct more literature reviews to modify the current methodology to obtain better performance for music education in China.

\section{References}

[1] Law W W, Ho W C. Popular music and school music education: Chinese students' 
preferences and dilemmas in Shanghai, China[J]. International Journal of Music Education, 2015.

[2] Yang Y, Welch G. Contemporary challenges in learning and teaching folk music in a higher education context: a case study of Hua'er music[J]. Music Education Research, 2014, 16(2):193-219.
[3] Zhao X, College P E, University Z. The Inspiration of Chinese Traditional Music Ideology for Quality Education[J]. Journal of Zaozhuang University, 2014.

[4] Yu J J. Understanding Chinese American Parents: The Interplay of Chinese Tradition and Early Childhood Music Education in the United States[J]. Dissertations \& Theses Gradworks, 